\title{
PERFORMA AYAM KAMPUNG SUPER YANG DI BERI LEVEL PENAMBAHAN TEPUNG KULIT KAKAO (Theobroma cacao, L.) FERMENTASI DALAM RANSUM
}

\author{
Syafar Abidin Pakaya1), Srisukmawati Zainudin'2), Safriyanto Dako') \\ 1. Alumni Program studi peternakan Fakultas pertanian Uuniversitas Negeri Gorontalo \\ 2. Jurusan Peternakan Fakultas Pertanian Universitas Negeri Gorontalo \\ syafar.pakaya94@gmail.com, zainudinsrisukmawati@gmail.com, sdako@ung.ac.id
}

\begin{abstract}
This research aims to find out the appearance of free-range chicken fed with the addition og cocoa skin flour (Theobroma cacao L.)fermented in feeds.the design used is a Completely Randomixed Design with four treatmens and four tepetitions. The parameters observed and measured are the amount of feed consumption, body weight gain, and feed conversion. The data analysis used is the analysis of variance. The findings show that addition of famented cocoa skin flour in level $0 \%, 5 \%$, $10 \%$ do not significantly $\mathrm{b}$ influence $(\mathrm{P}>0.05)$ on the feed consumption,body weight gain and the value of feed conversion in free-range chicken. The conlusion is the additional level of fermented cocoa skin flour to the level of $15 \%$ does not influence the appearance of free-range chicken.
\end{abstract}

Keywords: Free-Range Chicken,Cocoa Skin, Fermentation

\section{PENDAHULUAN}

\section{Latar Belakang}

Perkembangan dalam bidang sektor peternakan di Indonesia saat ini sangatlah pesat, sejalan dengan meningkatnya kesadaran masyarakat akan pentingnya nilai gizi bersumber dari hewani, salah satunya berasal dari ternak ayam kampung jenis super. Usaha peternakan ayam kampung super sangat potensial untuk dikembangkan, ayam kampung super memiliki pertumbuhan yang lebih cepat dibanding ayam kampung (buras), dimana masa pemeliharaan panen membutuhkan waktu 55-60 hari serta efisien dalam pengunaan ransum.

Ayam kampung super adalah ayam kampung yang berasal dari hasil persilangan antara ayam petelur dan ayam kampung.
Ayam kampung super dalam pemeliharaannya membutuhkan pakan yang berkualitas untuk pemenuhan nutrisinya, sebab pakan yang sempurna dengan kandungan zat nutrisi yang seimbang akan memberikan hasil yang optimal. Kenyataan yang di hadapi saat ini bahwa harga pakan komersial di pasaran sangat mahal (roboh, 2015). Pakan merupakan komponen terbesar dalam usaha peternakan unggas, biaya pakan tersebut dapat mencapai $60-70 \%$ dari total biaya produksi, sehingga sangatlah penting untuk mencari alternatif lain dalam ketersediaan bahan pakan untuk ransum. Upaya untuk mengatasi masalah pakan dengan jalan memanfaatkan potensi bahan pakan lokal yang ada, salah satunya dengan memanfaatkan limbah tanaman pangan berupa limbah dari kulit kakao (Roswita 2014). 
Tanaman kakao (Theobroma cacao, L) atau biasa disebut dengan cokelat merupakan tanaman yang tumbuh di daerah tropis. Di Indonesia tanaman kakao sendiri tersebar sebagian besar di beberapa pulau seluruh wilayah Indonesia, diantaranya di pulau Jawa, Sumatera, Kalimantan, Sulawesi, dan Papua. Berdasarkan survei lapangan kulit buah kakao dibuang begitu saja, tanpa ada yang memanfaatkan. Potensinya kulit buah kakao dapat dijadikan sebagai pakan alternatif ternak baik ruminansia maupun unggas. Ketersediaan kulit buah kakao cukup banyak karena sekitar $75 \%$ dari satu buah kakao utuh adalah berupa kulit buah, sedangkan biji kakao sebanyak 23\% dan plasenta 2\% (Wawo, (2008) dalam bungatang, 2016).

Komposisi buah kakao terdiri dari $74 \%$ kulit, 24\% biji kakao dan 2\% plasenta. Berdasarkan komposisi tersebut, kulit buah kakao merupakan komposisi terbesar dari produksi buah kakao (sari 2012). Nasrullan dan Ela (1993) melaporkan bahwa kakao mengandung 22\% protein dan 3-9\% lemak. Potensi kandungan nutrisi ini memungkinkan dijadikan sebagai pakan alternatif bagi ternak. Limbah kakao bisa menghasilkan bahan konsentrat yang harganya relatif terjangkau. Menurut Guntoro (2006) bahwa pemanfaatan limbah dapat meningkatkan produktivitas (pertumbuhan, produksi susu, telur dan lainlain).

Fermentasi merupakan pengolahan secara biologi, yaitu pengolahan dengan memanfaatkan mikroorganisme yang akan menghasilkan enzim untuk melakukan perubahan terhadap molekul kompleks seperti protein, karbohidrat dan lemak menjadi molekul yang lebih sederhana. Mikroorganisme yang dapat digunakan untuk fermentasi adalah Aspergillus niger. Pemanfaatan kulit kakao dengan proses fermentasi diharapkan mampu meningkatkan potensi kulit kakao sebagai bahan pakan alternatif yang berkualitas tinggi dan dapat mempengaruhi kandungan protein, lemak dan serat kasar kulit kakao (Anonim, 2010). Sari (2012) melaporkan bahwa 'kuliat kakao yang difermentasi dengan menggunakan Aspergillus niger mampu meningkatkan nilai nutrisi limbah kulit kakao, yaitu kandungan protein meningkat dari $9,88 \%$ menjadi $17,12 \%$ dan kandungan serat kasar turun yakni dari 7,10\% menjadi $4,15 \%$.

Informasi penggunaan kulit kakao yang difermentasi sebagai bahan pakan alternatif bagi ternak ayam kampung super masih terbatas, sehingga hal inilah yang mendasari penulis melakukan penelitian dengan judul "Penampilan ayam kampung super yang di beri level penambahan tepung kulit kakao(Theobroma cacao L.)fermentasi dalam ransum".

Tujuan penelitian adalah untuk mengetahui penampilan ayam kampung super yang di beri level penambahan kulit kakao (Theobroma cacao, $L$ ) fermentasi dalam ransum.

Manfaat yang dapat diperoleh dari penelitian adalah sebagai sumber informasi ilmiah untuk pengembangan sumber daya bahan pakan lokal pada ternak unggas khususnya auam kampuong dan sebagai upaya mengurangi pencemaran limbah pertanian.

\section{METODE PENELITIAN}

Proses pengolahan kulit kakao di cacah untuk memperkecil ukuran kulit lalu sediakan larutan Aspergillus niger dengan perbandingan tiga gram aspergilus niger dan satu kilogram kulit buah kakao, akan tetapi sebelum digunakan Aspergillus niger dilarutkan dengan air steril tanpa kaporit. Seperti air mata air atau air sumur yang bersih, bisa menggunakan air hujan atau air sungai tetapi harus dimasak lebih dahulu kemudian didinginkan Ke dalam air steril yang dingin dimasukkan gula pasir, urea dan NPK kemudian dilarutkan,Setelah di larutkan, kulit buah kako di masukan ke dalam palstik dan di tutup rapat agar tak ada udara yang masuk, setelah itu diamkan plastik yang berisi kulit buah kakao selama 4-5 hari. Setelah proses fermentasi selesai, keluarkan kulit buah kakao yg telah di fermentasi dan di jemur hingga kering selama 2-3 hari setelah proses pengeringan selesai kulit buah kakao di giling sampai menjadi tepung halus sebelum di berikan pada ternak (Sari, 2012).

Rancangan penelitian yang digunakan dalam penelitian adalah Rancangan Acak Lengkap (RAL) dengan 4 perlakuan dan masing-masing perlakuan di ulang 4 kali. Setiap ulangan terdiri atas 5 ekor, sehingga jumlah ternak ayam kampung super yang digunakan sebanyak 80 ekor. Model 
matematika yang di gunakan menurut Hanifah (2010) adalah:

$$
\boldsymbol{Y} \boldsymbol{i} \boldsymbol{j}=\boldsymbol{\mu}+\mathrm{ti}+\sum \boldsymbol{i} \boldsymbol{j}
$$

Keterangan :

$Y i j=$ hasil pengamatan dari perlakuan ke-i dan ulangan ke-j

$\mu$ =nilai rata-rata (mean) harapan

$t i \quad=$ pengaruh perlakuan ke-I dan ulangan kej

$\sum i j=$ pengaruh galat perlakuan ke-i dan ulanganke-j

Ransum percobaan terdiri dari :.

R0 : $0 \%$ kulit buah kakao tanpa fermentasi

R1 : 5\% fermentasi kulit buah kakao

R2 : 10\% fermentasi kulit buah kakao

R3 : 15\% fermentasi kulit buah kakao

Tabel 1. Komposisi ransum perlakuan

\begin{tabular}{lcccc}
\hline Bahan Pakan & R0 & R1 & R2 & R3 \\
\hline Kulit kakao & 0.0 & 5.0 & 10.0 & 15.0 \\
AD 1 & 100.0 & 95.0 & 90.0 & 85.0 \\
\hline \multicolumn{1}{c}{ Total } & 100 & 100 & 100 & 100 \\
\hline $\begin{array}{l}\text { kandungan } \\
\quad \text { nutrisi }\end{array}$ & R0 & R1 & R2 & R3 \\
\hline $\begin{array}{l}\text { Bahan } \\
\text { Kering (\%) }\end{array}$ & 5.00 & 5.67 & 6.34 & 7.01 \\
$\begin{array}{l}\text { Protein (\%) } \\
\text { Energi }\end{array}$ & 21.00 & 20.76 & 20.52 & 20.28 \\
$\begin{array}{l}\text { Metabolisme } \\
\text { (Kkal/kg) }\end{array}$ & 3100.00 & 3054.94 & 3009.88 & 2964.82 \\
$\begin{array}{l}\text { Serat Kasar } \\
\text { (\%) }\end{array}$ & 5.00 & 5.99 & 6.97 & 7.96 \\
$\begin{array}{l}\text { Lemak (\%) } \\
\text { Ca (\%) }\end{array}$ & 7.00 & 6.72 & 6.43 & 6.15 \\
P (\%) & 0.90 & 0.87 & 0.83 & 0.80 \\
\hline $\begin{array}{l}\text { Harga } \\
\text { (Rupiah) }\end{array}$ & 9000.00 & 8575.00 & 8150.00 & 7725.00 \\
\hline
\end{tabular}

Variabel yang diamati dalam penelitian adalah:

a. Pertambahan bobot badan (g/ekor/minggu) yang di peroleh dengan mengurangi bobot badan akhir (g/ekor) dengan bobot badan awal (g/ekor) dari ayam, yang dilakukan setiap minggu.

$$
\mathrm{PBB}=\frac{B B t-(\text { BBt }-1)}{\text { jumlahayam }}
$$

Keterangan:

$\mathrm{PBB}=$ Pertambahan berat badan
$\mathrm{BBt}=$ Berat badan akir minggu

BBt-1=Berat badan minggu

sebelumnya

b. Konsumsi ransum (g/ekor/hari) di ukur dengan cara mengurangi jumlah ransum (g) yang di berikan dengan jumlah sisa ransum (g) keesokan harinya.

Konsumsi pakan $=\frac{\text { Konsumsiransum }}{\text { pertambahanberatbadan }}$

c. Konversi ransum di hitung dengan cara membagi konsumsi ransum ayam dengan pertambahan bobot badan ayam.

Konversi

ransum $=\frac{\text { ransumyangdiberikan }- \text { ransumsisa }}{\text { jumlahayam }}$

\section{HASIL DAN PEMBAHASAN}

\section{Konsumsi ransum}

Hasil pengamatan selama penelitian tersadi pada tabel 2 .

Table 2. Rataan konsumsi ransum, pertambahan bobot badan, konversi ransum.

\begin{tabular}{lcccc}
\hline \multirow{2}{*}{ Variabel } & \multicolumn{4}{c}{ Perlakuan } \\
\cline { 2 - 5 } & R0 & R1 & R2 & R3 \\
\hline Konsumsi ransum & 26.16 & 25.75 & 25.83 & 24.93 \\
\hline $\begin{array}{l}\text { Pertambahan } \\
\text { bobot badan }\end{array}$ & 8.67 & 8.46 & 6.80 & 8.33 \\
\hline Konversi ransum & 3.02 & 3.195 & 2.58 & 3.24 \\
\hline Konsumsi & ransum & adalah & proses
\end{tabular}

masuknya sejumlah unsur nutrisi yang ada didalam ransum yang telah tersusun dari berbagai bahan pakan untuk memenuhi kebutuhan ayam. Konsumsi ransum dihitung berdasarkan jumlah pakan yang diberikan dalam sehari kemudian dikurangi dengan penimbangan sisa ransum selama satu minggu kemudian dibagi dengan jumlah ayam.

Hasil analisis of variance pada Tabel 5 . menunjukkan bahwa pemberian level penambahan fermentasi tepung kulit kakao dalam ransum pada setiap perlakuan tidak berbeda nyata $(\mathrm{P}>0,05)$ terhadap konsumsi pakan ayam kampung super. Jumlah ransum yang dikonsumsi pada semua perlakuan tidak berbeda nyata, hal ini dapat berarti bahwa level penambahan fermentasi tepung kulit kakao dalam ransum sampai pada level $15 \%$ belum memberikan pengaruh nyata pada konsumsi ransum. 
Gambaran konsumsi ransum ayam kampung yang diberi level penambahan kulit kakao fermentasi dalam ransum, tersaji pada Gambar 2.

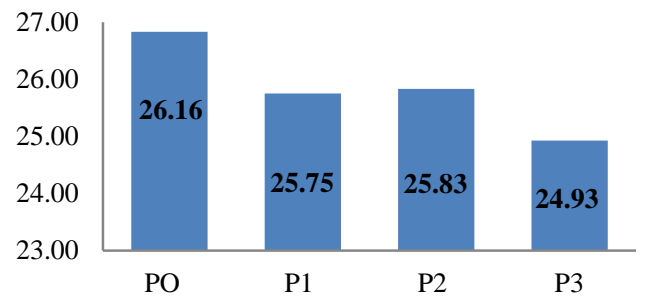

Gambar 1. memperlihatkan bahwa konsumsi ransum ayam kampung super menurun dari level pemberian $5 \%$ sampai $15 \%$. Konsumsi tertinggi pada perlakuan R0 sebesar 26,18 $\mathrm{g} /$ ekor/hari dan terendah pada perlakuan R3 sebesar 24,93 g/ekor/hari. Hal ini dapat menunjukkan bahwa konsumsi ransum ayam menurun dengan bertambahnya level pemberian tepung kulit kakao fermentasi dalam ransum. Diduga bahwa, menurunnya konsumsi ransum dipengaruhi oleh palatabilitas dari ransum perlakuan. Palatabilitas ransum dipengaruhi oleh bentuk, bau, rasa dan suhu ransum yang diberikan (Cruch, 1979 dalam Martini 2002). Selanjutnya Tillman et al., (1989) menyatakan bahwa konsumsi ransum dipengaruhi oleh bentuk dan fisik pakan, dan komposisi kimia ransum, frekuensi pemberian dan anti nutrisi dalam ransum. Kandungan serat kasar dari ransum perlakuan (Tabel 4.) meningkat sejalan dengan bertambahnya level fermentasi tepung kulit buah kakao, kandungan serat kasar yang tinggi akan menurunkan tingkat konsumsi.

\section{Pertambahan bobot badan}

Pertambahan bobot badan (pbb) ayam dihitung dengan mengurangkan bobot badan akhir (g/ekor) dengan bobot badan awal (g/ekor) kemudian dibagi lama waktu pemeliharaan (hari).

Hasil analisis of variance pada Tabel 6 . menunjukkan bahwa perlakuan penambahan level penambahan fermentasi tepung kulit kakao dalam ransum tidak berpengaruh nyata $(\mathrm{P}>0.05)$ terhadap pertambahan bobot badan ayam kampung super. Ayam yang diberi ransum kontrol (R0) dan ransum perlakuan (R1, R2, R3) menghasilkan pertambahan bobot badan yang sama besarnya, jadi level penambahan fermentasi tepung kulit kakao sampai pada level $15 \%$ belum berpengaruh nyata terhadap pertambahan bobot badan ayam kampung super.

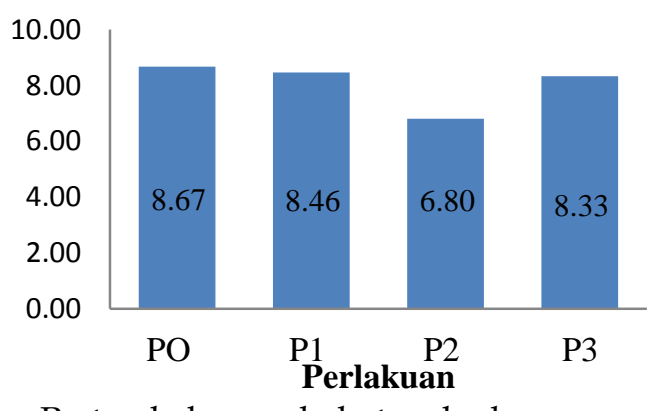

Pertambahan bobot badan ayam kampung yang diberi level penambahan fermentasi tepung kulit kakao dalam ransum, ditunjukkan pada gambar 3 .

Pertambahan bobot badan ayam kampung super tertinggi terdapat pada perlakuan R0 sebesar 8,67 g/ekor/hari dan terendah terdapat pada perlakuan R2 yaitu 6,80 g/ekor/hari. Hal ini dapat menunjukkan bahwa pertambahan bobot badan ayam kampung super yang di beri level penambahan fermentasi tepung kulit kakao dalam ransum menurun dengan bertambahnya level pemberian tepung kulit kakao. Ichwan (2003) menyatakan bahwa, secara umum penambahan bobot badan akan di pengaruhi oleh jumlah konsumsi pakan yang di makan dan kandungan nutrisi yang terdapat dalam pakan tersebut. Pernyataan ini juga di dukung oleh North dan Bell (1990) bahwa peningkatan pertambahan bobot badan di pengaruhi oleh konsumsi pakan jika konsumsi pakan baik maka pertambahan bobot badan akan baik pula.

\section{Konversi ransum}

Rataan konversi ransum pada setiap perlakuan selama penelitian menunjukan perlakuan penambahan level penambahan fermentasi tepung kulit kakao tidak berpengaruh nyata $(\mathrm{P}>0.05)$ terhadap konversi ransum ayam kampung super. Hal ini di sebabkan bahwa konversi ransum pada ransum kontrol maupun perlakuan lainnya memiliki nilai yang sama atau tidak berbeda nyata begitu pula halnya yang terjadi pada pertambahan bobot badan. Selain itu nilai konversi yang sama memperlihatkan bahwa 
semua ransum mempunyai tingkat efisiensi yang sama.

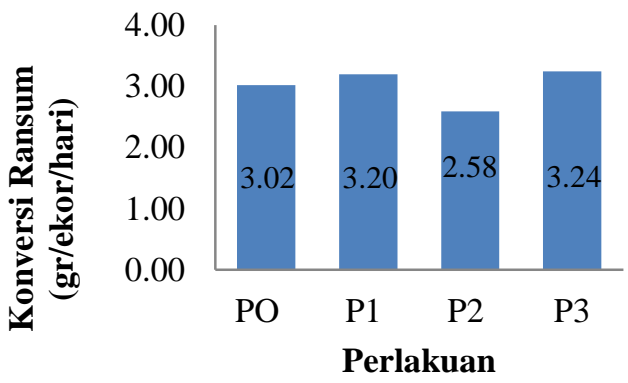

Gambar 4.

Gambar 4. menunjukkan bahwa nilai konversi ransum ayam kampung super tertinggi terdapat pada perlakuan R3 yaitu 3,24 $\mathrm{g} /$ ekor/hari. Dan nilai konversi ransum ayam kampung super terendah terdapat pada perlakuan R0, R1, R2. Hal ini di duga dipengaruhi oleh bau dan bentuk dari ransum. Semakin tinggi level penambahan tepung fermentasi kulit kakao, maka bau pakan lebih menyengat dan bentuk pakan halus, sehingga pakan banyak yang berceceran,. Hal ini sesuai dengan penelitian yang telah dilakukan oleh (Zain (2011) dalam Setyaningrum $d k k, 2014$ ) menyatakan bahwa selain palatabilitas, faktor lain yang mempengaruhi konsumsi ransum yaitu kandungan nutrisi terutama energi dan protein ransum, bentuk ransum, faktor lingkungan, genetik, jenis kelamin, dan kondisi ternak. Begitu pula bau pakan, semakin tinggi level penambahan tepung fermentasi kulit kakao, semakin pekat pula bau yg dicium oleh ternak sehingga ternak tidak terlalu suka. (Ichwan (2003) dalam E. Y. Yulma), menyatakan bahwa faktor yang mempengaruhi konversi ransum agar efisien adalah energi ransum, kualitas pakan (termasuk kecernaan pakan) dan penyakit

\section{KESIMPULAN}

Berdasarkan hasil penelitian menunjukkan bahwa pemanfaatan fermentasi tepung kulit kakao sampai $15 \%$ dalam ransum memberikan pengaruh yang tidak nyata terhadap konsumsi ransum, pertambahan bobot badan dan nilai konversi ransum ayam kampng super.

\section{DAFTAR PUSTAKA}

Anonim. 2010. Pemanfaatan Limbah Kulit Buah Kakao.

http://onlinebuku.com/2009/01/06/pem anfaatan-limbah-kulitbuah-kakao. diakses pada tanggal 28 Oktober 2010.

Anonim. 2010. Mengolah limbah kulit kakao menjadi pakan ternak. http://disnaksulsel.info/indek.php?opti on=com_docmanEtask $=d o c \_v i e w \mathcal{E} g i d$ $=10$. diakses pada tanggal 28 Oktober 2010.

Bagus, H. 2011. Petunjuk Praktis Pembesaran Ayam Kampung Pedaging. AgroMedia, Jakarta Selatan

Bungatang. 2006. Penggunaan Tepung Limbah Biji Kakao (Theobroma cacao, L.)Yang Difermentasi Bakteri Selulolitik Terhadap Produktivitas Ayam Petelur. Skripsi Fakultas Peternakan Universitas HasanuddinMakasar, Makasar.

Guntoro, S. dan I.M. Rai Yasa. 2005. Penggunaan Limbah Kakao Terfermentasi Untuk Pakan. Balai Pengkajian Teknologi Pertanian Bali Jl. By Pass Ngurah Rai Pesanggaran Denpasar-Bali

Guntoro, S. Sriyanto, N. Suyasa dan M. Rai Yasa. 2006. Pengaruh Pemberian Limbah Kakao Olahan Terhadap Pertumbuhan Sapi Bali. Balai Pengkajian Teknologi Pertanian Bali. Ngurahrai, Denpasar.

Maatua Egi. 2016 Level Pemberian Dedak Padi Fermentasi Dengan Cairan Rumen Dalam Ransum Terhadap Pertambahan Bobot Badan Ayam Kampung Super Fase Grower. Skripsi Fakultas Pertanian Jurusan Peternakan Universitas Gorontalo, Gorontalo

Martini. 2002 Pemanfaatan Kulit Buah Coklat Sebagai Pakan Alternatif Dalam Ransum Broiler. Skripsi. Fakultas Peternakan Universitas Andalas, Padang. 
Nursodik, 2016 Level Ampas Tahu Fermentasi Dalam Ransum Terhadap Pertambahan Bobot Badan Dan Konversi Ransum Burung Puyuh. Skripsi Fakultas Pertanian Jurusan Peternakan Universitas Gorontalo, Gorontalo

Pakan Ayam Buras Petelur Puslitbang Sosial Ekonomi Pertanian, Bogor. J. Pengkajian dan Pengembangan Teknologi Pertanian. Juli 2005.

Rasyaf, M. 1995. Pengolahan Usaha Peternakan Ayam Pedaging. Cetakan kedua. Penebar Swadaya, Jakarta.

Rasyaf, M. 2003. Makanan Ayam Pedaging. Kanisisus, Yogjakarta

Roboh H Rivon. 2015. Level Penambahan Nasi Aking Dalam Ransum Terhadap Pertambahan Bobot Badan, Konsumsi Dan Konversi Ransum Ayam Kampung Fase Stater Skripsi Fakultas Pertanian Jurusan Peternakan Universitas Gorontalo, Gorontalo

Rivay, Erwin. 2015. Tingkat Pemberian Dedak Padi Fermentasi Dengan Cairan Rumen Dalam Ransum Terhadap Pertambahan Bobot Badan Ayam Kampung Super Fase Stater Skripsi Fakultas Pertanian Jurusan Peternakan Universitas Gorontalo, Gorontalo

Roswita Ria.Pengaruh Pemberian Kulit Buah Kakao (Theobroma cacao,L.) Dalam Ransum Terhadap Pertumbuhan Ayam Broiler. http://jim.stkip-pgrisumbar.ac.id/jurnal/download/5574. Program Studi Pendidikan Biologi Sekolah Tinggi Keguruan dan Ilmu Pendidikan (STKIP) PGRI Sumatera Barat, padang. Diakses: April 2014

Sarwono, B. Sugito. 2004. Beternak Ayam Buras. Penebar Swadaya

Sudaryani, Titik, dan Santosa Hari. 2003. Pembibitan Ayam Buras. Penebar Swadaya, Jakarta
Suprijatna, E. 2005. Pengaruh Protein Ransum Saat Periode Pertumbuhan Terhadap Performans Produksi Telur Saat Periode Produksi Pada Ayam Ras Petelur Tipe Medium.Journal Indon.Trop.Anim.Agric. 30 (2) Juni 2005. . Cited by 5 Related articles

Sari Puspita RiaPemanfaatan Kulit Buah Kakao Sebagai Pakan Ternak.http://livestocklivestock.blogspot.co.id/2012/04/.Jurusa n Peternakan, Fakultas Pertanian, Universitas Bengkulu. Diakses : April 2012.

Wahyudi T, Pujianto dan Misnawi. 2015. Kakao Sejarah, Botani, Proses Produksi, Pengolahan Dan Perdagangan. Gadjah Mada University Press, Malang

Zainuddin, D., Sutikno, T. Haryadi dan Hernomoadi. 1995. Kecernaan dan Fermentasi Limbah Kakao Serta Pemanfaatannya Pada Ternak Ayam. Penebar Swadaya, Jakarta 